\title{
Association between interleukin-10 gene polymorphisms and susceptibility to diabetic nephropathy in a Chinese population
}

\author{
D.H. Ma ${ }^{1}$, Q.Y. Xu ${ }^{1}$, Y. Liu' ${ }^{1}$ Q.Q. Zhai ${ }^{2}$ and M.H. Guo ${ }^{1}$ \\ ${ }^{1}$ Department of Nephrology, \\ The First Affiliated Hospital of Xinxiang Medical University, Weihui, Henan, \\ China \\ ${ }^{2}$ Department of Endocrinology \& Metabolism, \\ The First Affiliated Hospital of Xinxiang Medical University, Weihui, Henan, \\ China \\ Corresponding author: D.H. Ma \\ E-mail: madongdh@163.com
}

Genet. Mol. Res. 15 (2): gmr. 15027570

Received September 1, 2015

Accepted November 19, 2015

Published May 6, 2016

DOI http://dx.doi.org/10.4238/gmr.15027570

\begin{abstract}
In this study, we investigated the association between the interleukin $(I L)-10-592 \mathrm{C} / \mathrm{A},-819 \mathrm{C} / \mathrm{T}$, and $-1082 \mathrm{G} / \mathrm{A}$ genetic variations and susceptibility to diabetic nephropathy in a Chinese population. The $I L-10-592 \mathrm{C} / \mathrm{A},-819 \mathrm{C} / \mathrm{T}$, and $-1082 \mathrm{G} / \mathrm{A}$ polymorphisms were genotyped in diabetic nephropathy patient and control samples by polymerase chain reaction-restriction fragment length polymorphism. The results were then statistically analyzed using SPSS 17.0. The results of the $\chi^{2}$ test revealed a significant difference in the frequencies of the GG, GA, and AA genotypes of $I L-10-1082 \mathrm{G} / \mathrm{A}$ between patients with diabetic nephropathy and control subjects $\left(\chi^{2}=10.03, \mathrm{P}=0.007\right)$. Unconditional logistic regression analysis revealed that the AA genotype of $I L-10-1082 \mathrm{G} /$ A significantly increased the susceptibility to diabetic nephropathy [adjusted odds ratio $(\mathrm{OR})=2.52,95 \%$ confidence interval
\end{abstract}


$(\mathrm{CI})=1.31-4.82]$ compared to the wild-type genotype. Moreover, the A allele of this polymorphism was associated with an increased risk of diabetic nephropathy compared to the $\mathrm{G}$ allele (adjusted $\mathrm{OR}=1.51$, $95 \% \mathrm{CI}=1.15-1.99)$. However, the $I L-10-819 \mathrm{~T} / \mathrm{C}$ and $-592 \mathrm{~A} / \mathrm{C}$ genetic polymorphisms did not increase the risk of diabetic nephropathy. In conclusion, the $I L-10-1082 \mathrm{G} / \mathrm{A}$ polymorphism was found to be correlated with the development of diabetic nephropathy.

Key words: Diabetic nephropathy; $I L-10-1082 \mathrm{G} / \mathrm{A} ; I L-10-819 \mathrm{~T} / \mathrm{C}$; IL-10 -592A/C; Polymorphism

\section{INTRODUCTION}

Diabetic nephropathy is the most prominent cause of end-stage renal disease, and is associated with high mortality in diabetic patients in both developed and developing countries (Dronavalli et al., 2008). The etiology of diabetic nephropathy is not well understood. Both environmental and lifestyle factors, such as high blood pressure, high body mass index (BMI), high glomerular filtration rate, high uric acid content, glycemic control, and ethnicity, are involved in the pathogenesis of diabetic nephropathy (Rossing et al., 2002). Additionally, genetic susceptibility may also play an important role in determining the development and severity of diabetic nephropathy (Tang et al., 2013).

Interleukin-10 (IL-10), produced by helper T (Th2) cells, is a well-known immune regulatory cytokine, which regulates T cells and monocytes/macrophages (D'Andrea et al., 1993). The $I L-10$ gene is located in chromosome $1 \mathrm{q} 31-1 \mathrm{q} 32$, and codes for a protein with a molecular weight of $4.7 \times 10^{3}$. Three common single nucleotide polymorphisms have been previously identified at the transcriptional start site in the $5^{\prime}$ flanking region of $I L-10$, which is a strong determinant for IL-10 production: a C-to-A substitution (C/A) at position -592 (rs1800872), a C-to-T substitution (C/T) at position -819 (rs1800871), and a G-to-A substitution (G/A) at -1082 (rs1800896) (Turner et al., 1997). Previous studies have reported that alterations in $I L-10$ levels are significantly associated with the urine albumin:creatinine ratio in diabetic nephropathy, which suggested that the aberrant production of inflammatory cytokines and chemokines could be the potential immunopathological mechanism of diabetic nephropathy (Wong et al., 2007). Another study reported that increased serum concentrations of inflammatory cytokines are correlated with the development of diabetic nephropathy (Konenkov et al., 2015). A few studies have reported the role of the $I L-10-592 \mathrm{C} / \mathrm{A},-819 \mathrm{C} / \mathrm{T}$, and $-1082 \mathrm{G} / \mathrm{A}$ polymorphisms in susceptibility to diabetic nephropathy, but with inconsistent results (Babel et al., 2006; Ezzidi et al., 2009; Mtiraoui et al., 2009; Kung et al., 2010; Arababadi et al., 2012; Erdogan et al., 2012). In this study, we have investigated the influence of the $I L-10-592 \mathrm{C} / \mathrm{A},-819 \mathrm{C} / \mathrm{T}$, and $-1082 \mathrm{G} / \mathrm{A}$ polymorphisms on the risk of diabetic nephropathy in a Chinese population.

\section{MATERIAL AND METHODS}

\section{Study subjects}

A total of 194 patients diagnosed with type 2 diabetes mellitus and diabetic nephropathy and 320 healthy control subjects were recruited to this study from the First Affiliated Hospital 
of Xinxiang Medical University between May 2012 and August 2014.

Patients were diagnosed with type 2 diabetes mellitus according to the criteria set by the World Health Organization (WHO) in 1999 (WHO, 1999). Diabetic nephropathy was diagnosed in diabetic patients based on the levels of proteinuria and glomerular filtration. Patients with a history of severe uncontrolled hypertension $(>160 / 100 \mathrm{mmHg})$, acute or chronic infectious disease, or cancer were excluded from the study. The mean age of patients with diabetic nephropathy was $53.56 \pm 10.55$ years, with males comprising $60.82 \%$ of all patients.

The controls were randomly selected from among individuals who underwent regular health examinations at our hospital between May 2012 and August 2014. The control subjects were confirmed to be free of diabetes and nephropathy, based on the fasting blood sugar level, and the levels of proteinuria and glomerular filtration. Individuals with a history of diabetes, diabetic nephropathy, acute or chronic infectious disease, or cancer were excluded from the control group. The mean age of control subjects was $50.65 \pm 9.61$ years, and males comprised $52.50 \%$ of all control subjects.

Patients with diabetic nephropathy and the control subjects were interviewed by trained nurses at the time of recruitment, in order to collect their demographic information. Clinical data was collected from medical records. Signed informed consent forms were obtained from all study subjects prior to enrollment. The study was approved by the Clinical Research Ethics Committee of the First Affiliated Hospital of Xinxiang Medical University.

\section{Genotyping}

Four-milliliter blood samples were obtained from all patients and control subjects, and were stored at $-20^{\circ} \mathrm{C}$ until use. Total genomic DNA was isolated from whole blood specimens using the QIAamp DNA Blood Mini kit (Qiagen, Valencia, CA, USA), according to the manufacturer instructions. The $I L-10-592 \mathrm{C} / \mathrm{A},-819 \mathrm{C} / \mathrm{T}$, and $-1082 \mathrm{G} / \mathrm{A}$ polymorphisms were genotyped by polymerase chain reaction-restriction fragment length polymorphism. The PCR primers for $I L-10-592 \mathrm{C} / \mathrm{A},-819 \mathrm{C} / \mathrm{T},-1082 \mathrm{G} / \mathrm{A}$, and the restriction enzymes used in this study are shown in Table 1. The PCR conditions were set as follows: initial denaturation at $94^{\circ} \mathrm{C}$ for $5 \mathrm{~min}$ and 30 cycles of denaturation at $94^{\circ} \mathrm{C}$ for $45 \mathrm{~s}$ and annealing at variable temperatures for $30 \mathrm{~s}$ and $72{ }^{\circ} \mathrm{C}$ for $45 \mathrm{~s}$. The resulting fragments were electrophoresed on a $2 \%$ agarose gel stained with ethidium bromide, in order to determine the genotypes of the patients and controls for both polymorphic sites.

Table 1. PCR primers and restriction enzymes.

\begin{tabular}{|c|c|c|c|c|}
\hline$I L-10$ & Forward primer $\left(5^{\prime}-3^{\prime}\right)$ & Reverse primer $\left(5^{\prime}-3^{\prime}\right)$ & $\begin{array}{l}\text { Length of digested } \\
\text { fragment (bp) }\end{array}$ & Restriction enzyme \\
\hline$-592 \mathrm{C} / \mathrm{A}$ & CCTAGGTCACAGTGACGTGG & GGTGAGCACTACCTGACTAGC & 412 & $R s a \mathrm{I}$ \\
\hline$-819 \mathrm{C} / \mathrm{T}$ & TCATTCTATGTGGTGGACATGG & TGGGCCAAGTGGGTAAGAGT & 209 & $M s I I$ \\
\hline$-1082 \mathrm{~A} / \mathrm{G}$ & ACTACTAAGGCTTCTTTGGGAA & CTACTAAGGCTTCTTTGGGAG & 258 & $M n l \mathrm{I}$ \\
\hline
\end{tabular}

\section{Statistical analysis}

Statistical variations between the demographic variables of the two study groups were statistically analyzed using an independent sample $t$-test and the chi-square $\left(\chi^{2}\right)$ test. The association between $I L-10$ polymorphisms and risk of diabetic nephropathy was determined by 
computing the odds ratio (OR) and $95 \%$ confidence intervals $(95 \% \mathrm{CI})$ from logistic regression analyses. The results were adjusted for possible confounding variables. A P value less than 0.05 was considered statistically significant. All statistical analyses were performed using the statistical software package SPSS 17.0 (SPSS Inc., Chicago, IL, USA).

\section{RESULTS}

Based on the results of the $\chi^{2}$ test, we observed significant differences in the mean age $(t=3.21, \mathrm{P}=0.001), \mathrm{BMI}\left(\chi^{2}=20.23, \mathrm{P}<0.001\right)$, hypertension status $\left(\chi^{2}=25.62, \mathrm{P}<\right.$ $0.001)$, triglyceride level $(t=16.54, \mathrm{P}<0.001)$, high-density lipoprotein level $(t=4.80, \mathrm{P}$ $<0.001)$, and low-density lipoprotein content $(t=1.86, \mathrm{P}=0.03)$ between the patients with diabetic nephropathy and control subjects (Table 2). However, we observed no significant differences in the gender $\left(\chi^{2}=3.39, \mathrm{P}=0.07\right)$, tobacco smoking status $\left(\chi^{2}=0.33, \mathrm{P}=0.57\right)$, alcohol consumption status $\left(\chi^{2}=0.49, \mathrm{P}=0.48\right)$, total cholesterol content $(t=1.46, \mathrm{P}=0.07)$, and creatinine levels $(t=1.26, \mathrm{P}=0.10)$ between these two groups.

Table 2. Demographic and clinical characteristics of patients with diabetic nephropathy and control subjects.

\begin{tabular}{|c|c|c|c|c|c|c|}
\hline Variables & Patients $(\mathrm{N}=194)$ & $\%$ & Controls $(\mathrm{N}=320)$ & $\%$ & \multirow{3}{*}{$\begin{array}{c}t \text { or } \chi^{2} \text { test } \\
3.21\end{array}$} & \multirow{3}{*}{$\begin{array}{c}\mathrm{P} \text { value } \\
0.001 \\
\end{array}$} \\
\hline Mean age (years) & \multicolumn{2}{|c|}{$53.56 \pm 10.55$} & \multicolumn{2}{|c|}{$50.65 \pm 9.61$} & & \\
\hline$<55$ & 84 & 43.30 & 156 & 48.75 & & \\
\hline$\geq 55$ & 110 & 56.70 & 164 & 51.25 & 4.76 & 0.03 \\
\hline \multicolumn{7}{|l|}{ Gender } \\
\hline Female & 76 & 39.18 & 152 & 47.50 & & \\
\hline Male & 118 & 60.82 & 168 & 52.50 & 3.39 & 0.07 \\
\hline \multicolumn{7}{|l|}{ BMI $\left(\mathrm{kg} / \mathrm{m}^{2}\right)$} \\
\hline$<24$ & 83 & 42.78 & 202 & 63.13 & & \\
\hline$\geq 24$ & 111 & 57.22 & 118 & 36.88 & 20.23 & $<0.001$ \\
\hline \multicolumn{7}{|l|}{ Hypertension } \\
\hline Yes & 87 & 44.85 & 216 & 67.50 & & \\
\hline No & 107 & 55.15 & 104 & 32.50 & 25.62 & $<0.001$ \\
\hline \multicolumn{7}{|l|}{ Tobacco smoking } \\
\hline No & 120 & 61.86 & 206 & 64.38 & & \\
\hline Yes & 74 & 38.14 & 114 & 35.63 & 0.33 & 0.57 \\
\hline \multicolumn{7}{|l|}{ Alcohol consumption } \\
\hline No & 114 & 58.76 & 198 & 61.88 & & \\
\hline Yes & 80 & 41.24 & 122 & 38.13 & 0.49 & 0.48 \\
\hline Triglyceride & & $8.21 \pm 2.87$ & & $4.92 \pm 1.64$ & 16.54 & $<0.001$ \\
\hline Total cholesterol & & $155.34 \pm 42.42$ & & $150.55 \pm 31.54$ & 1.46 & 0.07 \\
\hline High-density lipoprotein & & $183.24 \pm 21.43$ & & $172.50 \pm 26.30$ & 4.80 & $<0.001$ \\
\hline Low-density lipoprotein & & $45.43 \pm 11.58$ & & $43.25 \pm 13.60$ & 1.86 & 0.03 \\
\hline Creatinine & & $96.34 \pm 14.81$ & & $94.52 \pm 16.43$ & 1.26 & 0.10 \\
\hline Duration of diabetes (years) & & $13.53 \pm 2.85$ & & & & \\
\hline
\end{tabular}

The genotype distributions of the $I L-10-1082 \mathrm{G} / \mathrm{A},-819 \mathrm{~T} / \mathrm{C}$, and $-592 \mathrm{~A} / \mathrm{C}$ polymorphisms did not deviate from Hardy-Weinberg equilibrium in the patients ( $\mathrm{P}$ values $=0.82,0.44$, and 0.55 , respectively) and control subjects $(\mathrm{P}$ values $=0.35,0.18$, and 0.38 , respectively) (Table 3 ). The $\chi^{2}$ test revealed a significant difference in the GG, GA, and AA genotype frequencies of the $I L-10-1082 \mathrm{G} / \mathrm{A}$ polymorphism between patients with diabetic nephropathy and control subjects $\left(\chi^{2}=10.03, \mathrm{P}=0.007\right)$.

Unconditional logistic regression analysis revealed that the AA genotype of $I L-10$ $-1082 \mathrm{G} / \mathrm{A}$ significantly increased the susceptibility to diabetic nephropathy (adjusted OR $=$ $2.52,95 \% \mathrm{CI}=1.31-4.82$ ) compared to the wild type genotype (Table 4). Moreover, the A allele was associated with an increased risk of diabetic nephropathy compared to the $\mathrm{G}$ allele (adjusted $\mathrm{OR}=1.51,95 \% \mathrm{CI}=1.15-1.99$ ). However, logistic regression analysis of the $I L-10$ 
$-819 \mathrm{~T} / \mathrm{C}$ and $-592 \mathrm{~A} / \mathrm{C}$ polymorphisms showed no correlation between their genotypes and alleles and susceptibility to diabetic nephropathy.

Table 3. Distribution of $I L-10-1082 \mathrm{G} / \mathrm{A},-819 \mathrm{~T} / \mathrm{C}$, and $-592 \mathrm{~A} / \mathrm{C}$ gene polymorphisms.

\begin{tabular}{|c|c|c|c|c|c|c|c|c|}
\hline \multirow[t]{2}{*}{$\overline{\mathrm{SNP}}$} & \multirow[t]{2}{*}{ Patients } & \multirow[t]{2}{*}{$\%$} & \multirow[t]{2}{*}{ Controls } & \multirow[t]{2}{*}{$\%$} & \multicolumn{2}{|c|}{ P for HWE } & \multirow[t]{2}{*}{$\chi^{2}$ value } & \multirow[t]{2}{*}{$\mathrm{P}$ value } \\
\hline & & & & & Patients & Controls & & \\
\hline \multicolumn{9}{|c|}{$-1082 \mathrm{G} / \mathrm{A}$} \\
\hline GG & 71 & 36.60 & 154 & 48.13 & & & & \\
\hline GA & 94 & 48.45 & 141 & 44.06 & & & & \\
\hline $\mathrm{AA}$ & 29 & 14.95 & 25 & 7.81 & 0.82 & 0.35 & 10.03 & 0.007 \\
\hline \multicolumn{9}{|c|}{$-819 \mathrm{~T} / \mathrm{C}$} \\
\hline TT & 65 & 33.51 & 121 & 37.81 & & & & \\
\hline $\mathrm{TC}$ & 90 & 46.39 & 142 & 44.38 & & & & \\
\hline $\mathrm{CC}$ & 39 & 20.10 & 57 & 17.81 & 0.44 & 0.18 & 1.07 & 0.59 \\
\hline \multicolumn{9}{|c|}{$-592 \mathrm{~A} / \mathrm{C}$} \\
\hline $\mathrm{AA}$ & 69 & 35.57 & 126 & 39.38 & & & & \\
\hline$\overline{\mathrm{AC}}$ & 90 & 46.39 & 144 & 44.69 & & & & \\
\hline $\mathrm{CC}$ & 35 & 18.04 & 50 & 15.63 & 0.55 & 0.38 & 0.96 & 0.62 \\
\hline
\end{tabular}

$\mathrm{HWE}=$ Hardy Weinberg equilibrium.

Table 4. Association between $I L-10-1082 \mathrm{~A} / \mathrm{G},-819 \mathrm{~T} / \mathrm{C}$, and $-592 \mathrm{~A} / \mathrm{C}$ gene polymorphisms and risk of diabetic nephropathy.

\begin{tabular}{|c|c|c|c|c|c|c|}
\hline SNP & Patients & $\%$ & Controls & $\%$ & OR $(95 \% \mathrm{CI})^{1}$ & $P$ value \\
\hline \multicolumn{7}{|c|}{$-1082 \mathrm{~A} / \mathrm{G}$} \\
\hline GG & 71 & 36.60 & 154 & 48.13 & 1.0 (Ref.) & - \\
\hline $\mathrm{GA}$ & 94 & 48.45 & 141 & 44.06 & $1.45(0.97-2.16)$ & 0.06 \\
\hline AA & 29 & 14.95 & 25 & 7.81 & $2.52(1.31-4.82)$ & 0.002 \\
\hline \multicolumn{7}{|c|}{ Allele } \\
\hline $\bar{G}$ & 236 & 60.82 & 449 & 70.16 & 1.0 (Ref.) & - \\
\hline A & 152 & 39.18 & 191 & 29.84 & $1.51(1.15-1.99)$ & 0.002 \\
\hline \multicolumn{7}{|c|}{$-819 \mathrm{~T} / \mathrm{C}$} \\
\hline TT & 65 & 33.51 & 121 & 37.81 & 1.0 (Ref.) & - \\
\hline $\mathrm{TC}$ & 90 & 46.39 & 142 & 44.38 & $1.18(0.78-1.80)$ & 0.42 \\
\hline $\mathrm{CC}$ & 39 & 20.10 & 57 & 17.81 & $1.27(0.74-2.18)$ & 0.35 \\
\hline \multicolumn{7}{|c|}{ Allele } \\
\hline $\mathrm{T}$ & 220 & 56.70 & 384 & 37.80 & 1.0 (Ref.) & - \\
\hline $\mathrm{C}$ & 168 & 43.30 & 256 & 40.00 & $1.15(0.88-1.49)$ & 0.30 \\
\hline \multicolumn{7}{|c|}{$-592 \mathrm{~A} / \mathrm{C}$} \\
\hline AA & 69 & 35.57 & 126 & 39.38 & 1.0 (Ref.) & - \\
\hline $\mathrm{AC}$ & 90 & 46.39 & 143 & 44.69 & $1.15(0.76-1.74)$ & 0.49 \\
\hline $\mathrm{CC}$ & 35 & 18.04 & 50 & 15.63 & $1.28(0.73-2.22)$ & 0.36 \\
\hline \multicolumn{7}{|c|}{ Allele } \\
\hline A & 228 & 58.76 & 396 & 61.88 & 1.0 (Ref.) & - \\
\hline $\mathrm{C}$ & 160 & 41.24 & 244 & 38.12 & $1.14(0.87-1.49)$ & 0.32 \\
\hline
\end{tabular}

${ }^{1}$ Adjusted for age, gender, body mass index, hypertension, triglyceride, total cholesterol, high-density lipoprotein, low-density lipoprotein, and creatinine. $\mathrm{OR}=$ odds ratio; $\mathrm{CI}=$ confidence interval

\section{DISCUSSION}

Several studies conducted so far reveal a high amount of discrepancy in incidence of diabetic nephropathy between different ethnicities; that is, a high percentage of racial gathering has been observed in this disease. Therefore, we hypothesized that genetic heritage contributes to the development of diabetic nephropathy. In this study, we investigated the association 
between the $I L-10-1082 \mathrm{G} / \mathrm{A},-819 \mathrm{~T} / \mathrm{C}$, and $-592 \mathrm{~A} / \mathrm{C}$ polymorphisms and the development of diabetic nephropathy; the results of this study revealed that the $I L-10-1082 \mathrm{G} / \mathrm{A}$ polymorphism significantly influences the risk of diabetic nephropathy compared to the wild-type genotype in a Chinese population.

An increasing number of studies have reported an association between alterations in the interleukin gene and diabetes mellitus (Mandke and Singh, 2012; Habash et al., 2015; $\mathrm{Xu}$ et al., 2015). For example, Mandke and Singh (2012) reported that elevated expression of $I L-10$ played a protective role in autoimmune diabetes in mice. On the contrary, Habash et al. (2015) suggested that this proinflammatory cytokine promoted mitochondrial function and neurite outgrowth in cultured adult sensory neurons derived from normal and diabetic rats, while Xu et al. (2015) reported that $I L-10$ gene transfer downregulated the expression of inflammatory cytokines, attenuated pancreatic insulitis, and inhibited $\beta$ cell apoptosis, thereby reducing the incidence of diabetes in female non-obese diabetic mice. On the contrary, other studies have reported high concentrations of IL- $1 \beta$ and TNF- $\alpha$ in the vitreous fluid of patients with proliferative diabetic retinopathy (Demircan et al., 2006), as well as a correlation between aberrant production of inflammatory cytokines and chemokines and the immunopathological mechanism of diabetic nephropathy (Wong et al., 2007). These studies indicated that high expression of IL-10 may elevate diabetes susceptibility.

Several studies have also investigated the role of $I L-10$ polymorphisms in the development of diabetic nephropathy; however, the results of these studies are inconsistent (Babel et al., 2006; Ezzidi et al., 2009; Mtiraoui et al., 2009; Arababadi et al., 2012; Erdogan et al., 2012). Babel et al. (2006) reported an association between the GG genotype of the $I L-10-1082 \mathrm{G} /$ A polymorphism and an increased susceptibility to end-stage renal disease in German patients. Similarly, Ezzidi et al. (2009) reported an association between the $\mathrm{T}$ allele of $I L-10-819 \mathrm{~T} / \mathrm{C}$ and the development of type 2 diabetes in a Tunisian population, while Mtiraoui et al. (2009) summarized that genetic variations in the $I L-10$ promoter could affect the risk of nephropathy in patients with type 2 diabetes. Kung et al. (2010) also reported a significant association between the $-592 \mathrm{~A} / \mathrm{C}$ polymorphism in $I L-10$ and type 2 diabetic nephropathy, via altered IL-10 production. However, these results were not observed in two studies; that is, $I L-10$ polymorphisms were not correlated with susceptibility to type 2 diabetic nephropathy (Arababadi et al., 2012; Erdogan et al., 2012). In this study, we observed a significant correlation between the $I L-10-1082 \mathrm{G} / \mathrm{A}$ polymorphism and the risk of diabetic nephropathy in a Chinese population. However, these results must be validated by further studies.

This study has some limitations that must be addressed. First, the study subjects were recruited from a single area, which may not accurately represent other ethnicities. Second, the sample size included in this study was relatively small, which may affect the detection of a statistically significant difference between groups. Further large-scale studies are required to verify our findings.

In conclusion, we suggest that the $I L-10-1082 \mathrm{G} / \mathrm{A}$ polymorphism is correlated with the development of diabetic nephropathy. Studies with a larger sample size are required to confirm the role of polymorphisms in $I L-10$ in the risk of diabetic nephropathy.

\section{Conflicts of interest}

The authors declare no conflict of interest. 


\section{ACKNOWLEDGMENTS}

We would like to thank the staff of the First Affiliated Hospital of Xinxiang Medical University for their assistance in collecting blood samples for analysis.

\section{REFERENCES}

Arababadi MK, Reza Mirzaei M, Ali Sajadi SM, Hassanshahi G, et al. (2012). Interleukin (IL)-10 gene polymorphisms are associated with type 2 diabetes with and without nephropathy: a study of patients from the southeast region of Iran. Inflammation 35: 797-802. http://dx.doi.org/10.1007/s10753-011-9376-7

Babel N, Gabdrakhmanova L, Hammer MH, Schoenemann C, et al. (2006). Predictive value of cytokine gene polymorphisms for the development of end-stage renal disease. J. Nephrol. 19: 802-807.

D'Andrea A, Aste-Amezaga M, Valiante NM, Ma X, et al. (1993). Interleukin 10 (IL-10) inhibits human lymphocyte interferon gamma-production by suppressing natural killer cell stimulatory factor/IL-12 synthesis in accessory cells. J. Exp. Med. 178: 1041-1048. http://dx.doi.org/10.1084/jem.178.3.1041

Demircan N, Safran BG, Soylu M, Ozcan AA, et al. (2006). Determination of vitreous interleukin-1 (IL-1) and tumour necrosis factor (TNF) levels in proliferative diabetic retinopathy. Eye (Lond.) 20: 1366-1369. http://dx.doi. org $/ 10.1038 /$ sj.eye. 6702138

Dronavalli S, Duka I and Bakris GL (2008). The pathogenesis of diabetic nephropathy. Nat. Clin. Pract. Endocrinol. Metab. 4: 444-452.http://dx.doi.org/10.1038/ncpendmet0894

Erdogan M, Cetinkalp S, Ozgen AG, Saygili F, et al. (2012). Interleukin-10 (-1082G/A) gene polymorphism in patients with type 2 diabetes with and without nephropathy. Genet. Test. Mol. Biomarkers 16: 91-94. http://dx.doi.org/10.1089/ gtmb.2011.0075

Ezzidi I, Mtiraoui N, Kacem M, Mallat SG, et al. (2009). Interleukin-10-592C/A, -819C/T and -1082A/G promoter variants affect the susceptibility to nephropathy in Tunisian type 2 diabetes (T2DM) patients. Clin. Endocrinol. (Oxf.) 70: 401-407.http://dx.doi.org/10.1111/j.1365-2265.2008.03337.x

Habash T, Saleh A, Roy Chowdhury SK, Smith DR, et al. (2015). The proinflammatory cytokine, interleukin-17A, augments mitochondrial function and neurite outgrowth of cultured adult sensory neurons derived from normal and diabetic rats. Exp. Neurol. 273: 177-189. http://dx.doi.org/10.1016/j.expneurol.2015.08.016

Konenkov VI, Klimontov VV, Miakina NE, Tian NV, et al. (2015). Increased serum concentrations of inflammatory cytokines in type 2 diabetic patients with chronic kidney disease. Ter. Arkh. 87: 45-49.

Kung WJ, Lin CC, Liu SH and Chaung HC (2010). Association of interleukin-10 polymorphisms with cytokines in type 2 diabetic nephropathy. Diabetes Technol. Ther. 12: 809-813.http://dx.doi.org/10.1089/dia.2010.0085

Mandke R and Singh J (2012). Cationic nanomicelles for delivery of plasmids encoding interleukin-4 and interleukin-10 for prevention of autoimmune diabetes in mice. Pharm. Res. 29: 883-897. http://dx.doi.org/10.1007/s11095-011$\underline{0616-1}$

Mtiraoui N, Ezzidi I, Kacem M, Ben Hadj Mohamed M, et al. (2009). Predictive value of interleukin-10 promoter genotypes and haplotypes in determining the susceptibility to nephropathy in type 2 diabetes patients. Diabetes Metab. Res. Rev. 25: 57-63.http://dx.doi.org/10.1002/dmrr.892

Rossing P, Hougaard P and Parving HH (2002). Risk factors for development of incipient and overt diabetic nephropathy in type 1 diabetic patients: a 10-year prospective observational study. Diabetes Care 25: 859-864. http://dx.doi. org/10.2337/diacare.25.5.859

Tang ZH, Fang Z and Zhou L (2013). Human genetics of diabetic vascular complications. J. Genet. 92: 677-694. http:// dx.doi.org/10.1007/s12041-013-0288-1

Turner DM, Williams DM, Sankaran D, Lazarus M, et al. (1997). An investigation of polymorphism in the interleukin-10 gene promoter. Eur. J. Immunogenet. 24: 1-8. http://dx.doi.org/10.1111/j.1365-2370.1997.tb00001.x

WHO (1999). Study Group Report of a WHO Consultation Part 1. Diagnosis and classification of diabetes mellitus. World Health Organization, Geneva.

Wong CK, Ho AW, Tong PC, Yeung CY, et al. (2007). Aberrant activation profile of cytokines and mitogen-activated protein kinases in type 2 diabetic patients with nephropathy. Clin. Exp. Immunol. 149: 123-131. http://dx.doi. org/10.1111/j.1365-2249.2007.03389.x

Xu A, Zhu W, Li T, Li X, et al. (2015). Interleukin-10 gene transfer into insulin-producing $\beta$ cells protects against diabetes in non-obese diabetic mice. Mol. Med. Rep. 12: 3881-3889. 